\title{
Archer, Elisabeth, Richard Marggraf Turley \& Howard Thomas, Food and the Literary Imagination, Hampshire: Palgrave, 2014.
}

\author{
Recensão de Fátima Vieira \\ CETAPS/ Universidade do Porto
}

Food and the Literary Imagination resulta do trabalho colaborativo de três docentes da Universidade de Aberystwyth, no País de Gales. 0 caso não mereceria referência se os docentes não fossem de áreas académicas diferentes: Jayne Elisabeth Archer faz investigação sobre representações da alquimia, da ciência e das pseudo-ciências na literatura do início da Idade Moderna; Richard Margraaf Turley é especialista no período Romântico, interessando-se particularmente pela obra poética de Keats; e Howard Thomas tem formação em Biologia e Ciências Rurais e do Ambiente, com interesses investigativos na área da genética, evolução e usos de plantas comestíveis. 0 livro em apreço, embora assinado conjuntamente pelos três autores, é reflexo claro destas diferentes formações.

O volume é constituído por um Prólogo, seis capítulos e um Epílogo. O Prólogo apresenta o argumento principal sobre o qual todo o livro foi construído: a ideia de que não é a primeira vez que a humanidade enfrenta problemas graves de segurança alimentar. A solução proposta pelos autores é que olhemos para o passado e, com os nossos "olhos modernos", examinemos as soluções então adoptadas para a resolução dos problemas e as atualizemos, quando pertinente, para o nosso tempo.

O primeiro capítulo, "Food Matters", é sem dúvida o que de mais interesse se reveste 
pela forma como evidencia a centralidade do tema da alimentação, nomeadamente no que respeita às "disputas alimentares" que tantas vezes estiveram na base de rebeliões, ao longo da história do Ocidente. Reconhecendo o trabalho pioneiro de E. P. Thompson em relação aos food riots que, no século XVIII inglês, se constituíram como a forma mais genuína de ação popular direta, os autores evidenciam que o próprio Shakespeare retratara já, na sua obra dramática, situações de revolta popular motivadas pela escassez alimentar, contrastando com o exibicionismo dos banquetes aristocráticos caracterizados por uma política de excesso e desperdício. Seguindo a receita prescrita no Prólogo, os autores investem, ainda no primeiro capítulo, na construção de uma ponte entre o passado e o presente, caracterizando os desafios que temos de enfrentar neste dealbar do século XXI no âmbito de uma sociedade crescentemente urbanizada e sem capacidade para produzir, armazenar e distribuir alimentos com qualidade e em quantidade suficiente para que todos os seres humanos possam manter um estilo de vida saudável e activo. As duas últimas secções do primeiro capítulo levam-nos de regresso à literatura do passado e a diferentes formas de representação da alimentação e de aspectos da vida humana que lhe estão associados e que ainda hoje reconhecemos como significativos.

Ao lermos o segundo capítulo, "The Field in Time”, não nos ficam dúvidas de que terá sido redigido por Howard Thomas, embora possa ter naturalmente beneficiado do contributo dos outros dois autores. Nele encontramos uma análise informada da relação entre o ser humano e o campo e da forma como, desde o início da história humana, ele faz parte integrante da nossa identidade. Natureza selvagem, campos cultivados - o capítulo passa em revista um conjunto significativo de textos que descrevem paisagens pastoris, aráveis e naturais, numa consideração cuidada dos diferentes contextos históricos, cosmovisões particulares e implicações sócio-económicas.

0 terceiro e o quarto capítulos, respectivamente “Chaucer’s Pilgrims and a Medieval Game of Food" e "Remembering the Land in Shakespeare's Plays", têm o interesse de, para além de ofereceram uma análise cuidada das representações da alimentação na obra de Chaucer e de Shakespeare, contextualizarem a ligação que os próprios autores tinham aos circuitos de produção e distribuição alimentar. Na verdade, se o estudo da relação das 
personagens dos Contos da Cantuária com a comida e a bebida não constitui, em si, grande novidade (tendo em conta que os peregrinos contam histórias na perspectiva de poderem ganhar uma refeição), poucos saberão que a carreira profissional de Chaucer lhe proporcionou um conhecimento direto comida enquanto mercadoria. Neto de vitivinicultores, Chaucer assumiu, ao longo de doze anos, a função de Controlador da Alfândega do Porto de Londres, supervisionando a importação e exportação de bens, entre eles produtos alimentares. Apercebeu-se das disfunções do sistema alimentar, da especulação a que os alimentos estavam sujeitos, das relações de poder que se criavam nos circuitos de produção e distribuição, estando pois habilitado para deles falar com propriedade. Da mesma forma, a singularidade do capítulo sobre Shakespeare reside na oferta do retrato do bardo como um homem de negócios astuto, que constituiu fortuna à custa da especulação com a compra e venda de terras e com a armazenagem (ilegal, em tempos de escassez) de malte e milho. A consideração das cenas em que, nas suas peças, Shakespeare critica as formas de gestão da distribuição alimentar e dos recursos naturais não pode de facto descurar o apontamento biográfico do autor com que Food and the Literary Imagination nos brinda.

Os quinto e sexto capítulos ("Keats 'To Autumn': Touching the Stubble-Plains" e "George Eliot and the New Agronomy") mostram como o tema da alimentação ganhou protagonismo quer na poesia romântica de Keats quer na escrita realista de Eliot. A análise do poema "To Autumn" desvela, num poema aparentemente sobre a abundância, a tensão provocada pela disputa de terras e pelo direito ao processamento e distribuição de produtos alimentares, contextualizando-a no âmbito de um debate de dimensões nacionais sobre a regulamentação de preços e a relação entre a terra e o trabalho. Já a leitura que nos é oferecida de The Mill on the Floss destaca a forma como George Eliot utilizou o velho moinho como símbolo de um modelo de produção, distribuição e consumo alimentar colocado em perigo pela nova economia industrial.

o Epílogo relembra a relevância da literatura para o problema alimentar, salientando que, ontem como hoje, ela proporciona o espaço ideal para um exercício imaginativo sobre possibilidades e alternativas em que é essencial investir, como o 
argumento conclusivo denota: "A alimentação, o futuro da alimentação, não pode ser deixado aos governos, aos bancos e aos supermercados. A alimentação e o seu futuro são da responsabilidade de poetas, dramaturgos, romancistas, artistas, e de todos nós" (p. 165, tradução minha).

Food and the Literary Imagination merece a nossa atenção pela forma como nos propõe uma metodologia para o estudo da representação da alimentação em obras literárias baseada, por um lado, na procura de aspetos na biografia dos autores que evidenciem um conhecimento mais particular da matéria e, por outro lado, na atenção dada a aspectos que poderão parecer pouco importantes, mas que se encontram imbricados na questão alimentar. Apesar do interesse desta abordagem, o livro enferma de uma superespecialização dos diferentes capítulos que o constituem e que são, como foi já salientado, directa consequência dos interesses investigativos dos autores. Para além disso, embora o livro assente no pressuposto de que vale a pena olharmos para o passado para nele discernirmos estratégias para a construção do nosso futuro, esse processo nem sempre é tornado evidente, ficando-se pela mera constatação de que os problemas são semelhantes. Estes aspetos não tiram contudo o mérito ao livro, que prima por uma linguagem fluente e cuidada, e que propõe modos alternativos e produtivos de leitura de textos canónicos. 